\title{
Helical organization of chiral binaphthyl tetrathiafulvalene primary amides through hydrogen bonding interactions ${ }^{\dagger}$
}

\author{
Ali Saad, Olivier Jeannin and Marc Fourmigué* \\ Received 16th March 2010, Accepted 11th May 2010 \\ DOI: 10.1039/c004320f
}

Chiral tetrathiafulvalenes, $(R)$ or $(S)$, or racemic, $(R, S)$, are obtained from a phosphite-mediated cross coupling reaction of a 1,3-dithiole-2-thione derivative bearing one binaphthol moiety, and are transformed into binaphthol-based tetrathiafulvalene ortho-diamides. The X-ray crystal structures of five intermediate chiral 1,3-dithiole-2-one and 1,3-dithiole-2-thione derivatives reveal the formation of helical structures through $\pi-\pi$ interactions. The binaphthol-based tetrathiafulvalene ortho-diamides, as THF or DMSO solvates, adopt different solid-state organisations, characterised either by short intramolecular hydrogen bonds or with solely intermolecular hydrogen bonds and chiral solid-state structures with short intermolecular S $\cdots \mathrm{S}$ contacts.

In the research effort on multifunctional organic materials, ${ }^{1}$ the introduction of chirality in molecular conductors has been encouraged by the observation of a new phenomenon, referred to as the electrical magneto-chiral anisotropy effect, experimentally observed by Rikken et al. in the magneto-transport properties of chiral carbon nanotubes. ${ }^{2}$ As many organic conductors are based on cation radical salts of tetrathiafulvalene derivatives, two main routes are currently actively developed toward chiral conducting organic salts, ${ }^{3}$ based on either chiral tetrathiafulvalene (TTF) donor molecules, or on chiral counter ions used as electrolyte in electrocrystallisation experiments. ${ }^{4,5}$ These different approaches were recently reviewed by Avarvari and Wallis. ${ }^{3}$ The chiral TTFs described so far essentially involve the point chirality of tetrahedral carbon atoms, as for example in alkyl derivatives of bis(ethylenedithio)tetrathiafulvalene (BEDT-TTF) and analogs, ${ }^{3,6}$ or in TTF functionalized with chiral oxazolines. ${ }^{7}$ However, in the few cation radical salts obtained with these chiral donor molecules, the organic stacks or slabs still adopt a pseudo-centrosymmetric structure and the whole conducting fraction of the salts hardly bears chiral information. We postulated that the introduction, on a tetrathiafulvalene core, of the more sterically demanding chiral 1,1'-binaphthol moiety, commercially available with very high enantiomeric purity, ${ }^{8}$ would favour chiral solid-state organisations through a combination of $\pi-\pi$ interactions and overlap interactions of open-shell molecules. Only a few TTF derivatives incorporating a binaphthyl moiety have been described to date. They are all based on one single binaphthyl platform bearing two TTF moieties, through either conjugated ${ }^{9}$ or non-conjugated linkers, ${ }^{10,11}$ affording in all cases highly flexible molecules. Such optically active dyads were described as chiral molecular switches through circular dichroism modulation upon oxidation, ${ }^{\mathbf{1 0}}$ and were used for the formation of intramolecular dyads. ${ }^{9,11}$ Looking

Sciences Chimiques de Rennes, Université Rennes 1, UMR CNRS 6226, Campus de Beaulieu, 35042 Rennes, France.E-mail: marc.fourmigue@ univ-rennesl.fr

$\dagger$ CCDC reference numbers 737671, 761559 and 769799-769806. For crystallographic data in CIF or other electronic format see DOI: $10.1039 / \mathrm{c} 004320 \mathrm{f}$ for a more rigid association between the TTF core and the binaphthol chiral moiety, we recently developed the preparation of the enantiopure $(R, R)-,(S, S)$ - and meso-bis(binapthol) TTF derivatives such as $[(R, R)-\mathbf{1}]$, showing that the enantiopure $(R, R)-\mathbf{1}$ or $(S, S)-\mathbf{1}$ donor molecules were able to self associate upon oxidation into mixed valence dyads, at variance with the (meso)-1 whose geometry hindered such association. ${ }^{12}$

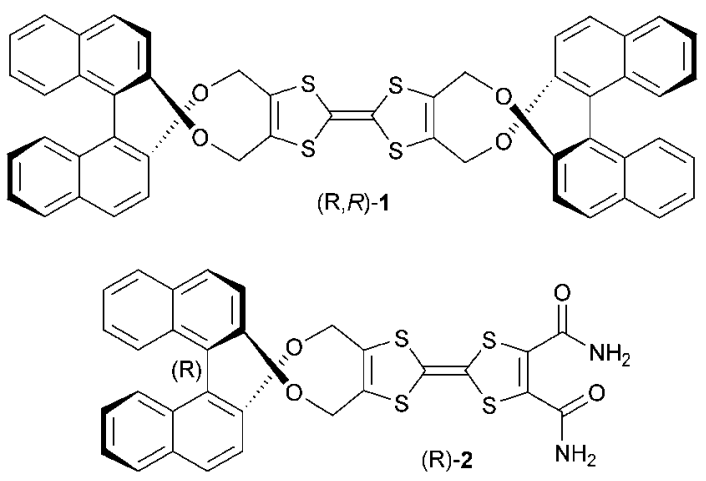

The strong steric requirements imposed by the rigidity of the side rings in $\mathbf{1}$ limited the possibilities for extended intermolecular interactions in the solid state. It was therefore advisable to consider asymmetrically substituted TTF which would bear a chiral binaphthyl moiety only on one side of the molecule. Furthermore, in order to induce a truly chiral effect on the organic stacks, we also envisioned hydrogen bonding as an appropriate tool to control the solid-state structure of such chiral binaphthyl-substituted TTFs into chiral helical structures. Indeed, found everywhere in nature, as in the DNA double helix, ${ }^{13}$ collagen triple helix ${ }^{14}$ or the $\alpha$-helical coiled coil of myosin, ${ }^{15}$ the spontaneous organisation of nonbiological species into helical structures through hydrogen bonding has been recognized as an efficient tool, ${ }^{16}$ as for example in polymers, ${ }^{17}$ surfactants, ${ }^{18}$ liquid crystals, ${ }^{19}$ fluorescent oligomers ${ }^{20}$ or gels. ${ }^{21}$ Complete asymmetric induction of supramolecular chirality was recently achieved in a hydrogen-bonded assembly of enantiopure calix[4]arene dimelamines and 5,5-diethylbarbituric acid. ${ }^{22}$ It is 
therefore anticipated that the inherent chirality of the binaphthyl moiety could be transferred to the whole solid-state organisation of the TTF molecules through hydrogen bonding interactions. Such interactions were shown to be particularly strong in various achiral tetrathiafulvalenyl amides, ${ }^{23}$ both in their neutral ${ }^{24}$ or oxidized forms. ${ }^{25,26} \mathrm{We}$ therefore decided to combine on the same TTF platform, the chirality of the binaphthyl moiety together with the hydrogen bonding capability of amido substituents, as shown here in the ortho-diamides $(R)-\mathbf{2}$ or $(S)-\mathbf{2}$.

We report here on the syntheses of the chiral TTF-based donor molecule 2 bearing two primary amide substituents in its chiral $(R),(S)$ and racemic $(R, S)$ form, together with its electrochemical properties. We also describe the solid-state properties of intermediate 1,3-dithiole-2-thione and 1,3-dithiole-2-one synthetic intermediates, together those of the enantiopure bisamides $(R)-\mathbf{2}$ and $(S)-2$, in different solvated (THF, DMSO) crystalline forms, demonstrating that the combination of hydrogen bonding and $\pi-\pi$ interaction can indeed favour helical organisations in the solid state.

\section{Results and discussion}

\section{Syntheses}

The preparation of the bis(amide) derivatives $\mathbf{2}$ is based on the amination of the corresponding diester $\mathbf{5}$, itself obtained through a phosphite-mediated cross coupling of the chiral 2-thioxo-1,3dithiole $^{\mathbf{1 2}}$ 3a with an excess of 4,5-bis(methyloxycarbonyl)-2thioxo-1,3-dithiole 4, as shown in Scheme 1. Note that the same cross coupling reaction performed with the 1,3-dithiole-2-one derivatives $\mathbf{3 b}$, isolated from the usual oxymercuration reaction from 3a, afforded the expected diester $\mathbf{5}$ only in very low yields. All reactions were performed on the two enantiopure $(R)$ - and $(S)$-3a as well as on the racemic mixture $(R, S)$-3a, affording the enantiopure $(R)$-, $(S)$ - and racemic $(R, S)$-2 bisamides in comparable yields. This amination reaction is based on a protocol initially

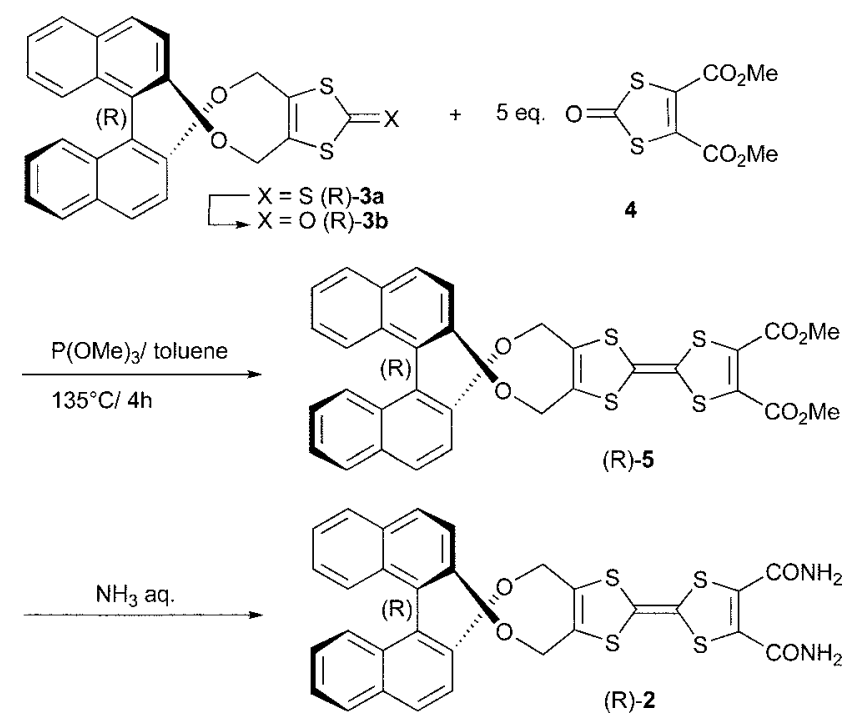

Scheme 1 Synthetic route to the bisamide 2, shown here for the $(R)$ isomer.
Table 1 Redox potentials of the TTF molecules $\mathbf{2}$ and $\mathbf{5}$ and reference compounds (in V vs. SCE, $\mathrm{CH}_{2} \mathrm{Cl}_{2}, 0.2 \mathrm{M} n-\mathrm{Bu}_{4} \mathrm{NPF}_{6}, 100 \mathrm{mV} \mathrm{s}^{-1}$ )
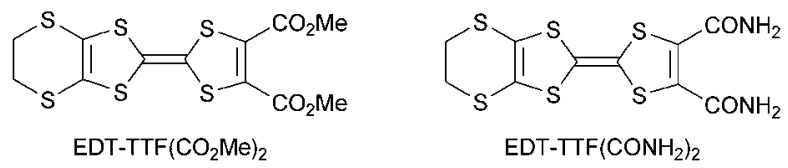

\begin{tabular}{lllll}
\hline Compound & $E_{1 / 2}^{1}$ & $E_{1 / 2}^{2}$ & Solvent & Ref \\
\hline$(R)-2$ & 0.58 & $1.06^{a}$ & $\mathrm{CH}_{2} \mathrm{Cl}_{2}$ & This work \\
$(S)-\mathbf{2}$ & 0.575 & $1.06^{a}$ & $\mathrm{CH}_{2} \mathrm{Cl}_{2}$ & This work \\
$(R, S)-2$ & 0.58 & $1.06^{a}$ & $\mathrm{CH}_{2} \mathrm{Cl}_{2}$ & This work \\
EDT-TTF $(\mathrm{CONH})_{2}$ & 0.73 & 0.96 & $\mathrm{THF}^{2}$ & $26 a$ \\
$(R)-5$ & 0.595 & 1.08 & $\mathrm{CH}_{2} \mathrm{Cl}_{2}$ & This work \\
$(S)-5$ & 0.595 & 1.08 & $\mathrm{CH}_{2} \mathrm{Cl}_{2}$ & This work \\
$(R, S)-5$ & 0.595 & 1.08 & $\mathrm{CH}_{2} \mathrm{Cl}_{2}$ & This work \\
EDT-TTF(COOMe $)_{2}$ & $0.64^{b}$ & $0.95^{b}$ & $\mathrm{CH}_{3} \mathrm{CN}$ & 28 \\
BEDT-TTF & 0.55 & 0.85 & $\mathrm{CHCl}_{2} \mathrm{CH}_{2} \mathrm{Cl}$ & 29 \\
$($ meso $)-1$ & 0.43 & 0.99 & $\mathrm{CH}_{2} \mathrm{Cl}_{2}$ & 12
\end{tabular}

${ }^{a} E_{\mathrm{ox}}$ value given, the return peak is affected by precipitation. ${ }^{b} v s$. $\mathrm{Ag} / \mathrm{AgCl}$.

described by Bryce et al. ${ }^{27}$ for $\operatorname{TTF}\left(\mathrm{CO}_{2} \mathrm{Me}\right)_{2}$ and further extended to $\operatorname{EDT}-\mathrm{TTF}\left(\mathrm{CO}_{2} \mathrm{Me}\right)_{2}$ by Batail et al. ${ }^{26}$

Cyclic voltammetry experiments were performed on all TTF derivatives to evaluate their donor ability, for further electrocrystallisation experiments. Data are collected in Table 1, together with those of reference compounds such as the bis(binapthol)TTF 1 in its meso form, and ethylenedithio derivatives such as EDT-TTF $(\mathrm{COOMe})_{2}$ and EDT-TTF $\left(\mathrm{CONH}_{2}\right)_{2}$. The TTF diamides 2 and diesters 5 exhibit two redox waves associated with the oxidation of the TTF moieties to the cation and dicationic state. No differences are found between enantiomers or with the racemic mixture. The first oxidation potential is systematically shifted toward cathodic potentials when compared with the EDT-TTF derivatives such as EDT$\mathrm{TTF}(\mathrm{COOMe})_{2}$ and EDT-TTF $\left(\mathrm{CONH}_{2}\right)_{2}$, demonstrating that the ethylenedithio substituent plays a stronger electron withdrawing effect than the binaphthol substituent, as also illustrated from the differences of redox potentials between the symmetrically substituted BEDT-TTF and $\mathbf{1}$ (Table 1, bottom).

\section{X-Ray crystal structures}

Good quality single crystals were obtained by recrystallisation, for the intermediate 1,3-dithiole-2-thione derivatives $(R)$-3a and $(S)-3 \mathbf{a}$ as well as for the 1,3-dithiole-2-one derivatives $(R)-\mathbf{3 b},(S)$ 3b and the racemic $(R, S)-3 \mathbf{b}$. For the TTF derivatives, crystals were analysed for the racemic $(R, S)-5$ and enantiopure $(R)-5$ diester molecules, the enantiopure $(R)-2$ bisamide as two different THF solvates, and the enantiopure $(S)-\mathbf{2}$ bisamide as a DMSO solvate. Among the ten crystal structures reported here, eight are related to enantiopure molecules and were accordingly found to crystallise in chiral space groups. Our main interest within these extensive series is to identify solid-state organisations with helical structures and to identify the pertinent intermolecular interactions which favour these motifs.

Crystal structures were obtained for the two enantiomers of the 1,3-dithiole-2-one, $(R)-3 \mathbf{b}$ and $(S)$-3b. They both crystallise in the monoclinic system, space group $P 2_{1}$, with two 


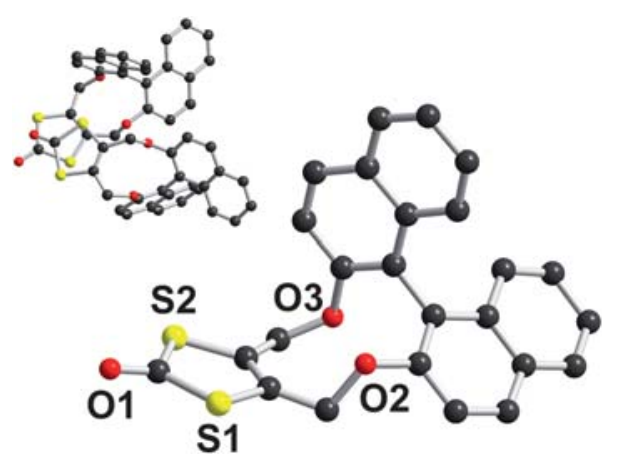

Fig. 1 View of the molecule in $(R)-3 b$. Inset: the bimolecular motif.

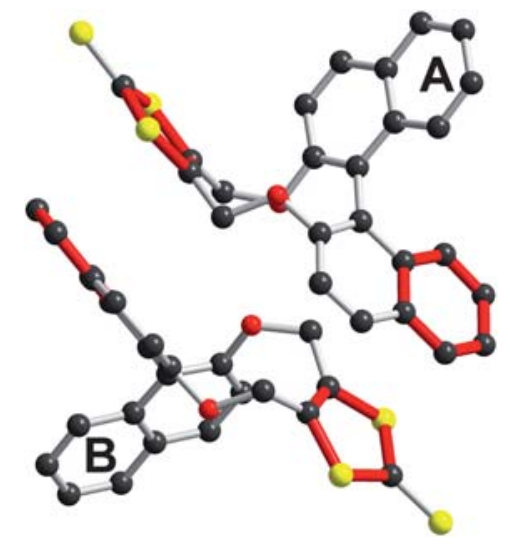

Fig. 2 The bimolecular motif formed from the two crystallographically independent $\mathrm{A}$ and $\mathrm{B}$ molecules in $(R)-\mathbf{3 a}$. The rings facing each other through $\pi-\pi$ interactions have been highlighted with red bonds.

crystallographically independent molecules (A and B) in the unit cell. As shown in Fig. 1, the molecules associate two-bytwo with the dithiole rings facing each other, however at $S \cdots S$ distances larger than the sum of van der Waals radii. Due to the constrained geometry of the ten-membered ring, the binaphthyl unit adopts a cisoid conformation with a twist angle between the two naphthyl units which amounts to 75.1(2) and $66.7(2)^{\circ}$, in molecules $\mathrm{A}$ and $\mathrm{B}$, respectively. Similar twist angles are found in binaphthol itself $\left(68^{\circ}\right),{ }^{30}$ as well as in 4,5,6,7-tetrahydrodinaphtho $\left(2,1-b: 1^{\prime}, 2^{\prime}-d\right)(1,6)$ dioxecine, a molecule where the two oxygen atoms of the binaphthol are simply linked by a tetramethylene bridge $\left(66.1\right.$ and $\left.74.1^{\circ}\right) .{ }^{31}$
Crystal structures were also obtained for the two enantiomers of the 1,3-dithiole-2-thione, $(R)-\mathbf{3 a}$ and $(S)$-3a. They crystallise in the trigonal system, in the enantiomorphic groups $P 3_{1}$ and $P 3_{2}$, respectively, with two crystallographically independent molecules in the unit cell together with one toluene molecule. As shown in Fig. 2, the two molecules face each other though $\pi-\pi$ interactions involving one aryl and one dithiole ring, highlighted in red. The shortest intermolecular $\mathrm{C} \cdots \mathrm{C}$ contacts amount to 3.50-3.60 $\AA$ while the dihedral angles between the rings facing each other amount to $7.8-8.0^{\circ}$. These bimolecular moieties further interact though $\pi-\pi$ interactions involving the remaining aryl groups (highlighted in blue in Fig. 3) along the $3_{1}$ axis running along $c$, with shortest $\mathrm{C} \cdots \mathrm{C}$ contacts at $3.45 \AA$ and a dihedral angle between planes of $7.2^{\circ}$.

Turning now to the TTF derivatives $\mathbf{5}$ and $\mathbf{2}$, the racemic diester $(R, S)-\mathbf{5}$ crystallises in the triclinic system, space group $P \overline{1}$, with one molecule in general position in the unit cell (Fig. 4). As unusual features, we note, (i) the folding of the dithiole rings along the $\mathrm{S} \cdots \mathrm{S}$ hinges, $\mathrm{S} 1 \cdots \mathrm{S} 2: 17.49(8)^{\circ}$, and $\mathrm{S} 3 \cdots \mathrm{S} 4: 3.69(8)^{\circ}$, as often observed with neutral TTF derivatives, (ii) the steric crowding on the diester side with one $\mathrm{CO}_{2} \mathrm{Me}$ in the TTF plane while the other one is twisted by $60.44(6)^{\circ}$, (iii) the rigidity of the ten-membered ring on the binaphthyl side with a twist angle between the two naphthyl units which amounts here to $63.06(6)^{\circ}$. In the solid state, the molecules are associated two-by-two into inversion centered heterochiral dyads (Fig. 5).

The enantiopure diester $(R)-\mathbf{5}$ crystallises in the monoclinic system, chiral space group $C 2$. It has essentially the same geometry than in $(R, S)-\mathbf{5}$, however with a flattening of the TTF moiety since the dithiole folding angles amount only to $6.3(2)$ and $3.8(2)^{\circ}$ along the $\mathrm{S} 1 \cdots \mathrm{S} 2$ and $\mathrm{S} 3 \cdots \mathrm{S} 4$ hinges, respectively. The twist angle between the two naphthyl units amounts here to

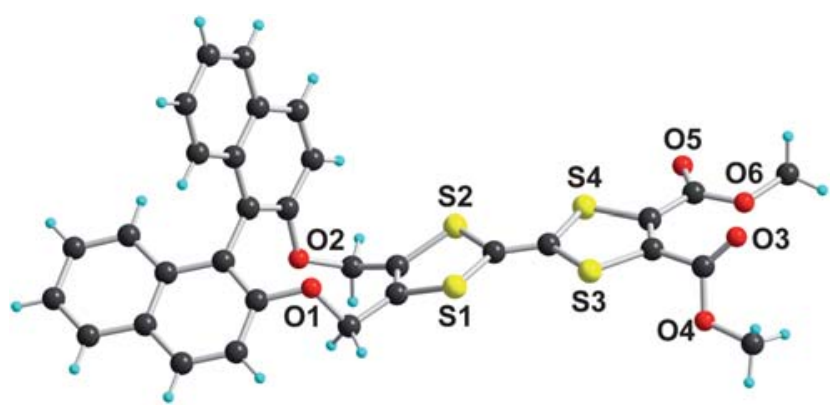

Fig. 4 Molecular view of the $(R)$-isomer in $(R, S)-5$.

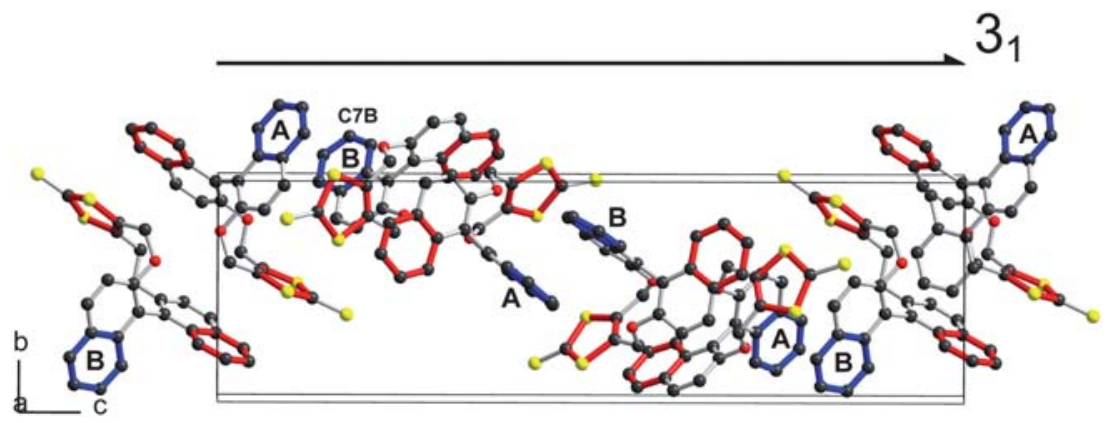

Fig. 3 Helical organisation of the bimolecular $\mathrm{AB}$ motifs in (R)-3a through $\pi-\pi$ interactions involving naphthyl rings (highlighted in blue). 


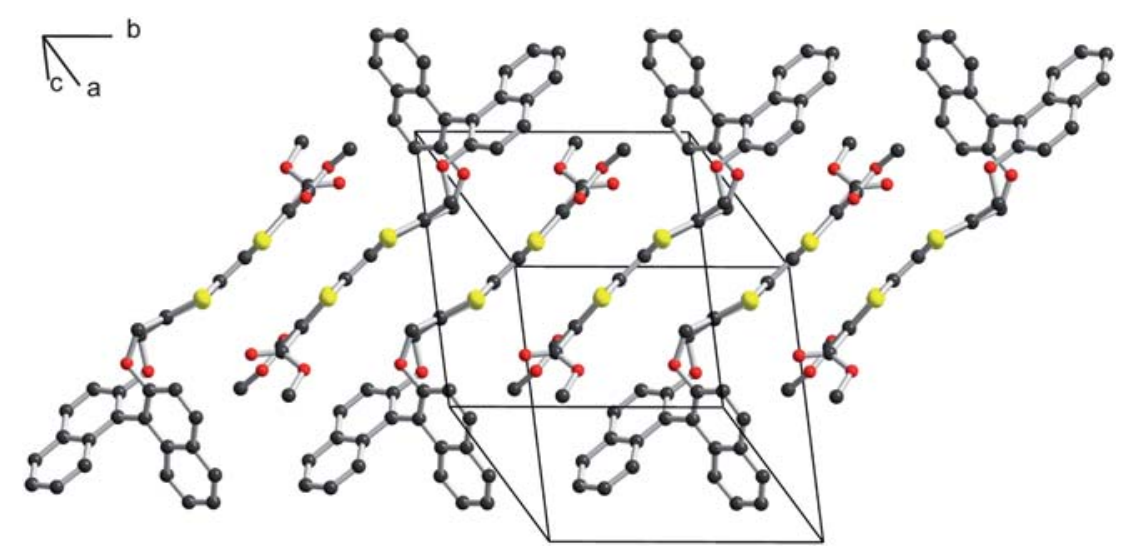

Fig. 5 Solid-state association into chains running along $b$ in $(R, S)-5$.

$64.0(1)^{\circ}$. In the solid state, the molecules are associated through the two-fold axis along $b$ into layers, without any face-to-face interaction between the planar TTF moieties.

The crystallisation of the enantiopure bisamide $(R)-2$ was performed by diffusion of pentane vapours above a THF solution. Dark red crystals were isolated on the glass surface at the pentane-enriched THF surface while orange crystals precipitated at the bottom of the THF solution. The dark red crystals analyse as a THF-poor $2: 1$ solvate, $(R)-\mathbf{2} \cdot(\mathrm{THF})_{0.5}$, while the orange crystals analyse as a THF-rich $1: 2$ solvate, $(R)-2 \cdot(\mathrm{THF})_{2}$. Both phases tend to decompose, probably by losing THF.

The THF-poor compound crystallises in the monoclinic system, chiral space group $P 2_{1}$, with two crystallographically independent molecules in the unit cell together with one THF molecule. As shown in Fig. 7, the geometry of the two donor molecules, on the binaphthyl side, is essentially the same in the two molecules and comparable to that observed above in the diester $(R)-\mathbf{5}$ or $(R, S)-\mathbf{5}$ (see Fig. 4). The hydrogen bonding capability of the two amido groups gives rise to the formation, in both crystallographically independent molecules, of an intramolecular $\mathrm{N}-\mathrm{H} \cdots \mathrm{O}$ hydrogen bond within a seven-membered cyclic motif, noted S(7) in Etter's nomenclature of hydrogen bond patterns, ${ }^{32}$ and commonly observed in ortho-diamides ${ }^{33}$ as well as in $\operatorname{EDT}-\mathrm{TTF}\left(\mathrm{CONH}_{2}\right)_{2}$ and its salts. ${ }^{26}$ Note that for a given common orientation of the binaphthyl moiety (Fig. 7), each of the two possible $\mathrm{N}-\mathrm{H} \cdots \mathrm{O}$ hydrogen bonds is observed, giving a rationale for the observation of two crystallographically independent molecules in this structure.

In the solid state, the two molecules combine with THF to afford a complex hydrogen-bonded network shown in Fig. 8, characterised by $\mathrm{R}_{2}^{2}(8)$ motifs based on $\mathrm{O} 1$ and $\mathrm{O} 1 \mathrm{~A}$ and characteristic of amide structures. These motifs develop by translation along the $a$ direction through $\mathrm{C}(8)$ motifs. Their geometrical features are collected in Table 2, and exhibit the typical characteristics of amide hydrogen bonds, also observed for example in TTF amides. ${ }^{24,25}$ Note also in Table 2 the much

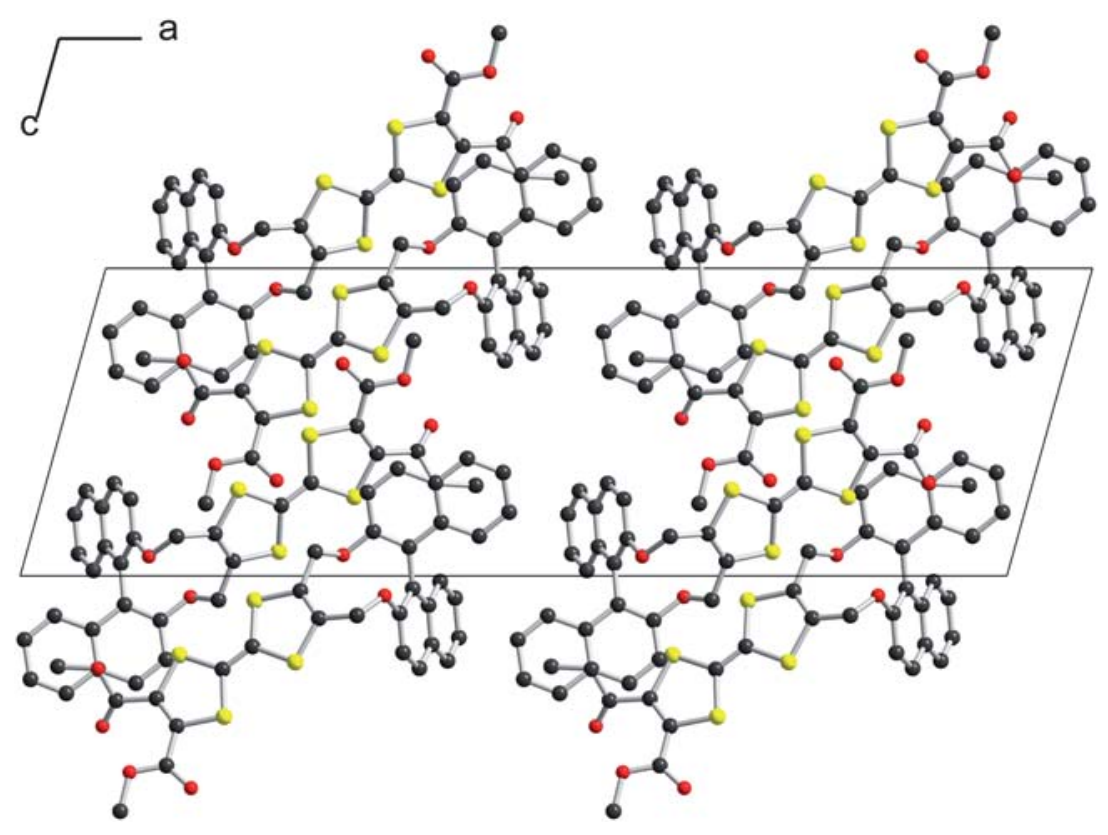

Fig. 6 Projection view along $b$ of the unit cell of $(R)-5$. 

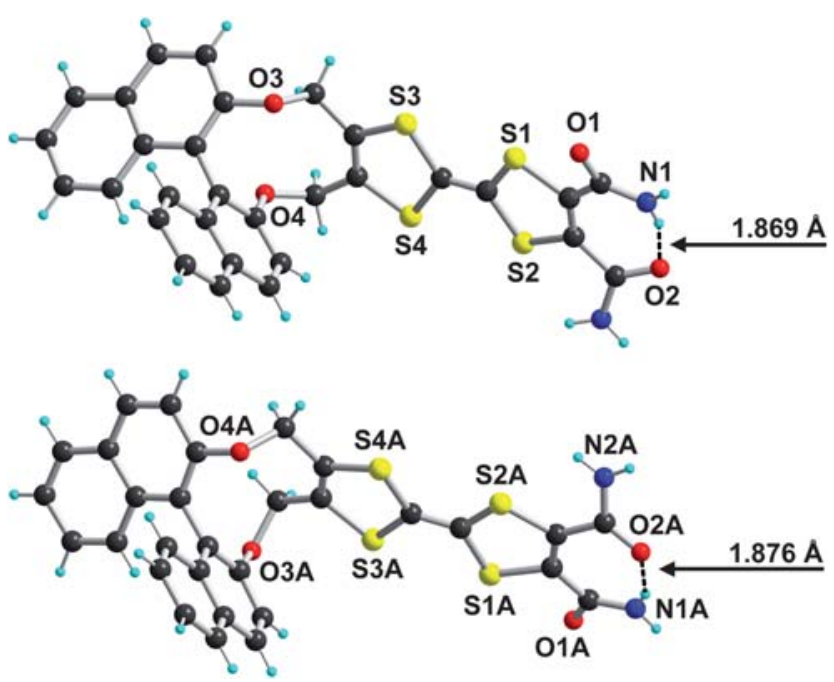

Fig. 7 View of the two crystallographically independent molecules in $(R)-\mathbf{2} \cdot(\mathrm{THF})_{0.5}$. Note, for the same binaphthyl orientation, the intramolecular $\mathrm{N}-\mathrm{H} \cdots \mathrm{O}$ motifs involving different $\mathrm{NH}_{2}$ moieties.

shorter intramolecular hydrogen bond, when compared with the intermolecular ones. ${ }^{26}$

The THF-rich solvate, $(R)-\mathbf{2} \cdot(\mathrm{THF})_{2}$, crystallises in the monoclinic system, chiral space group $P 2_{1}$. The ortho-bisamide motif adopts now an open structure, without any intramolecular hydrogen-bond pattern, at variance with the structure in $(R)$ 2. $(\mathrm{THF})_{0.5}$ as well as with all EDT-TTF $\left(\mathrm{CONH}_{2}\right)_{2}$ structures reported so far where a recurrent closed motif was observed. ${ }^{26}$ As a consequence, all $\mathrm{NH}_{2}$ hydrogen atoms are available for intermolecular hydrogen-bond interactions, characterised here with the recurrent formation of bimolecular cyclic motifs associating molecules along the two-fold axis (Fig. 9a) together with one of the two THF molecules (the other THF molecule is not engaged in hydrogen bonding). A very similar structure is found for the $(S)$ isomer, crystallised as a DMSO solvate and formulated as (S)-2·(DMSO) $)_{2}$ (Fig. 9b), where DMSO molecules disordered on two sites replace the THF molecules in $(R)-\mathbf{2} \cdot(\mathrm{THF})_{2}$.
Table 2 Hydrogen-bond characteristics in $(R)-\mathbf{2} \cdot(\mathrm{THF})_{0.5}$

\begin{tabular}{|c|c|c|c|c|}
\hline \multirow[b]{2}{*}{$\mathrm{NI}-\mathrm{H} 1 \mathrm{~B} \cdots \mathrm{O} 2$ (intra) } & \multicolumn{4}{|c|}{$\operatorname{Motif}^{32}(\mathrm{~N})-\mathrm{H} \cdots \mathrm{O} / \AA ̊ \AA \mathrm{N}(-\mathrm{H}) \cdots \mathrm{O} / \AA ̊ \AA \mathrm{N}-\mathrm{H} \cdots \mathrm{O} /{ }^{\circ}$} \\
\hline & $\mathrm{S}(7)$ & 1.87 & $2.69(3)$ & 158.5 \\
\hline $\mathrm{N} 1-\mathrm{H} 1 \mathrm{~A} \cdots \mathrm{O} 1 \mathrm{~A}$ & $\mathrm{R}_{2}^{2}(8)$ & 2.10 & $2.95(3)$ & 173.1 \\
\hline $\mathrm{N} 2-\mathrm{H} 2 \mathrm{~A} \cdots \mathrm{O} 1$ & $\mathrm{C}(8)$ & 2.05 & $2.90(5)$ & 167.1 \\
\hline $\mathrm{N} 2-\mathrm{H} 2 \mathrm{~B} \cdots \mathrm{O}_{\mathrm{THF}}$ & $\mathrm{D}$ & 2.11 & 2.91(1) & 152.4 \\
\hline $\mathrm{N} 1 \mathrm{~A}-\mathrm{H} 1 \mathrm{~A} 2 \cdots \mathrm{O} 2 \mathrm{~A}$ (intra) & $S(7)$ & 1.88 & $2.69(3)$ & 157.6 \\
\hline $\mathrm{N} 1 \mathrm{~A}-\mathrm{H} 1 \mathrm{~A} 1 \cdots \mathrm{O} 1$ & $\mathrm{R}_{2}^{2}(8)$ & 2.14 & 2.99(3) & 169.0 \\
\hline $\mathrm{N} 2 \mathrm{~A}-\mathrm{H} 21 \mathrm{~A} \cdots \mathrm{O} 1 \mathrm{~A}$ & $\mathrm{C}(8)$ & 2.11 & 2.93(3) & 159.2 \\
\hline $\mathrm{N} 2 \mathrm{~A}-\mathrm{H} 2 \mathrm{~A} 2$ & \multicolumn{4}{|c|}{ No hydrogen bond } \\
\hline
\end{tabular}

As shown in Fig. 10, the same $2_{1}$ axis running along $b$ also associates molecules two-by-two with remarkably short $\mathrm{S} \cdots \mathrm{S}$ contacts (Table 4), demonstrating here for the first time that an helical organisation of TTF-based molecules associated with a set of short $\mathrm{S} \cdots \mathrm{S}$ contacts, ${ }^{34}$ is indeed conceivable, a prerequisite for a sizeable conductivity in mixed-valence compounds.

In conclusion, we have shown here, based on the X-ray crystal structures of several chiral binaphthyl-substituted 1,3-dithiole and tetrathiafulvalene derivatives, that the combination of hydrogen bonding and $\pi-\pi$ interactions could indeed favour helical solid-state organisations, and concomitantly, as observed above in the ortho-bisamides $(R)-\mathbf{2} \cdot(\mathrm{THF})_{2}$ or $(S)-\mathbf{2} \cdot(\mathrm{DMSO})_{2}$, the formation of chiral chains with short $\mathrm{S} \cdots \mathrm{S}$ intermolecular contacts. These results open broad perspectives toward the elaboration of chiral cation radical salts upon oxidation of the redox active TTF moieties. Indeed, the combination of partially oxidized chiral donor molecules and recognition tools such as hydrogen bonding or halogen bonding 5 between the donor molecules and the counter ions provides a novel approach to control the solid-state organisation of the salts toward the formation of chiral molecular metals.

\section{Experimental}

\section{Syntheses}

The 1,3-dithiole-2-thiones $(R)-\mathbf{3 a},(S)$-3a and $(R, S)$-3a were prepared as previously described ${ }^{12}$ from the reaction of the corresponding

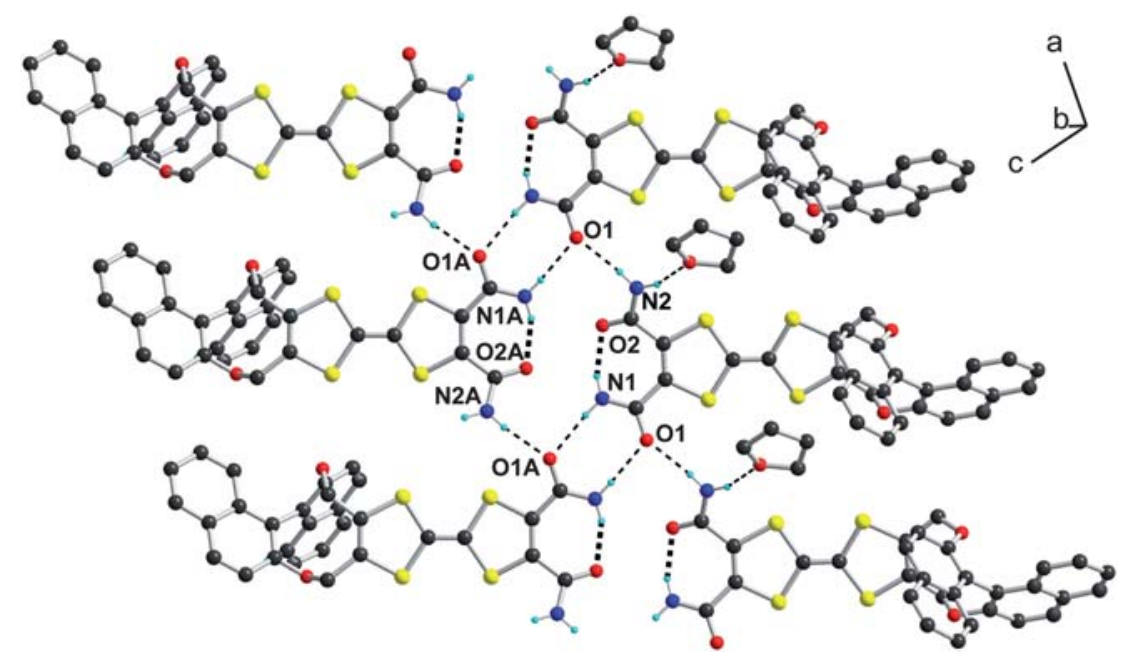

Fig. 8 Hydrogen-bond network in $(R)-2 \cdot(\mathrm{THF})_{0.5}$. 
(a)

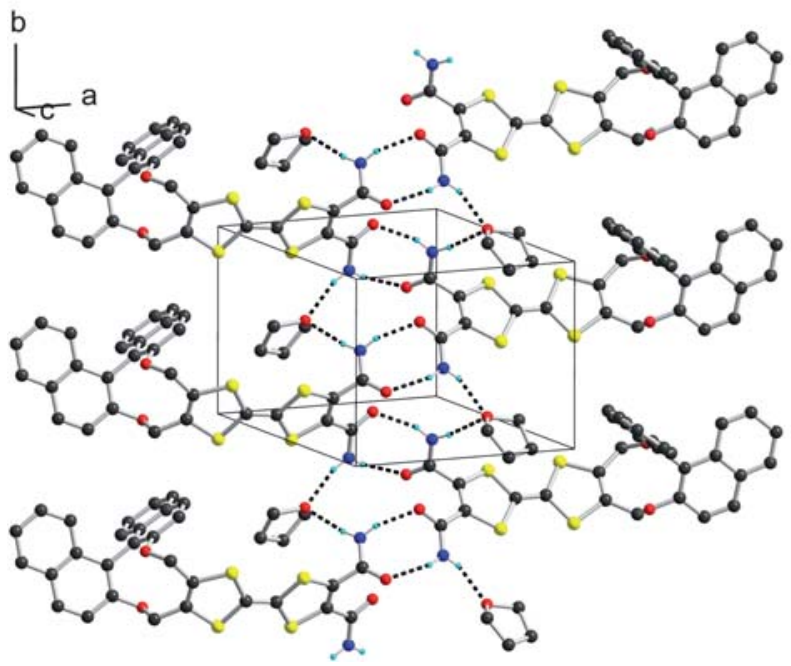

(b)

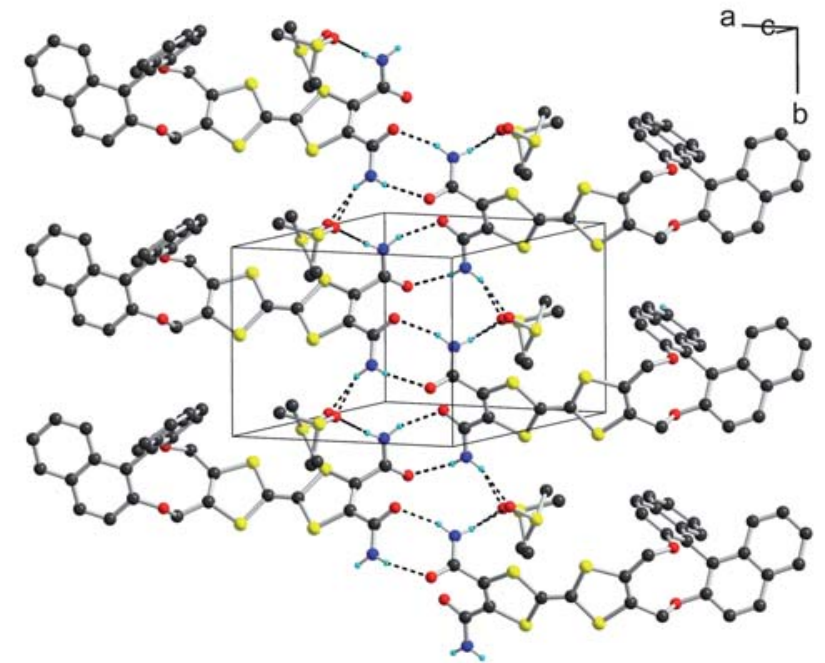

Fig. 9 View of the hydrogen-bonding network in (a) $(R)-\mathbf{2} \cdot(\mathrm{THF})_{2}$ and (b) $(S)-\mathbf{2} \cdot(\mathrm{DMSO})_{2}$, showing the bimolecular cyclic motifs and their association through the 2 axis along $b$.

Table 3 Hydrogen-bond characteristics in $(R)-2 \cdot(\mathrm{THF})_{2}$ and $(S)$ 2. $(\mathrm{DMSO})_{2}$

$\operatorname{Motif}^{32}(\mathrm{~N})-\mathrm{H} \cdots \mathrm{O} / \AA \mathrm{N} \mathrm{N}(-\mathrm{H}) \cdots \mathrm{O} / \AA \mathrm{A} \mathrm{N}-\mathrm{H} \cdots \mathrm{O} /{ }^{\circ}$

$(\boldsymbol{R})-2 \cdot(\mathrm{THF})_{2}$

$\mathrm{N} 1-\mathrm{H} 1 \mathrm{~A} \cdots \mathrm{O} 2$

$\mathrm{N} 1-\mathrm{H} 1 \mathrm{~B} \cdots \mathrm{O} 1 \mathrm{~A}_{\mathrm{THF}}$

$\mathrm{N} 2-\mathrm{H} 2 \mathrm{~A} \cdots \mathrm{O} 1$

\section{$\mathrm{R}_{2}^{2}(8) \quad 2.13$}

D $\quad 2.10$

$\mathrm{R}_{2}^{2}(8) \quad 2.04$

$\mathrm{N} 2-\mathrm{H} 2 \mathrm{~A} \cdots \mathrm{O} 1 \mathrm{~A}_{\mathrm{THF}}$

$\mathrm{D}$

2.13

$2.90(1)$

$2.87(1)$

$2.98(1)$

160.8

154.9

161.2

170.1

$(S)-2 \cdot(D M S O)_{2}$

$\begin{array}{lllll}\mathrm{N} 1-\mathrm{H} 1 \mathrm{~A} \cdots \mathrm{O} 2 & \mathrm{R}_{2}^{2}(8) & 2.16 & 2.991(4) & 160.8 \\ \mathrm{~N} 1-\mathrm{H} 1 \mathrm{~B} \cdots \mathrm{O} 1 \mathrm{C}_{\text {DMSO }} & \mathrm{D} & 2.06 & 2.87(1) & 158.9 \\ \mathrm{~N} 1-\mathrm{H} 1 \mathrm{~B} \cdots \mathrm{O} 1 \mathrm{D}_{\text {DMSO }} & \mathrm{D} & 1.99 & 2.74(4) & 144.7 \\ \mathrm{~N} 2-\mathrm{H} 2 \mathrm{~A} \cdots \mathrm{O} 1 & \mathrm{R}_{2}^{2}(8) & 2.04 & 2.863(8) & 160.3 \\ \mathrm{~N} 2-\mathrm{H} 2 \mathrm{~B} \cdots \mathrm{O} 1 \mathrm{C}_{\text {DMSO }} & \mathrm{D} & 2.03 & 2.88(1) & 171.6 \\ \mathrm{~N} 2-\mathrm{H} 2 \mathrm{~B} \cdots \mathrm{O} 1 \mathrm{D}_{\text {DMSO }} & \mathrm{D} & 1.98 & 2.82(2) & 167.0\end{array}$

(a)

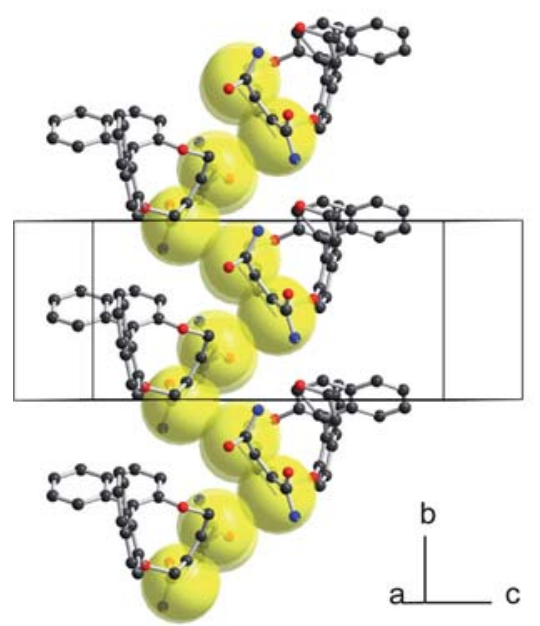

commercially available binaphthol derivatives, as $(R),(S)$ or racemic mixture, with 4,5-bis(bromomethyl)-1,3-dithiole-2thione. ${ }^{35}$

\section{Racemic 1,3-dithiole-2-one $(R, S)-3 b$}

To a solution of racemic 1,3-dithiole-2-thione $(R, S)-3 \mathbf{a}(0.3 \mathrm{~g}$, $0.674 \mathrm{mmol})$ in $\mathrm{CHCl}_{3}(4 \mathrm{~mL})$ under nitrogen was added a solution of mercuric acetate $(0.54 \mathrm{~g}, 2.5$ equiv. $)$ in glacial acetic acid $(5.5 \mathrm{~mL})$. After a few min, the solution turned into a milky green and changed to white over $15 \mathrm{~min}$. After stirring at r.t. for $4 \mathrm{~h}$, the precipitate was filtered using hyflo and washed thoroughly with $\mathrm{CH}_{2} \mathrm{Cl}_{2}$. The organic layer was washed twice with $1 \mathrm{M} \mathrm{NaHCO}_{3}$ solution $(75 \mathrm{~mL})$, dried $\left(\mathrm{MgSO}_{3 \mathrm{~b}}\right)$ and evaporated. Purification by column chromatography on silica gel $\left(\mathrm{CH}_{2} \mathrm{Cl}_{2}\right)$ gave $(R, S)-\mathbf{3 b}$ as

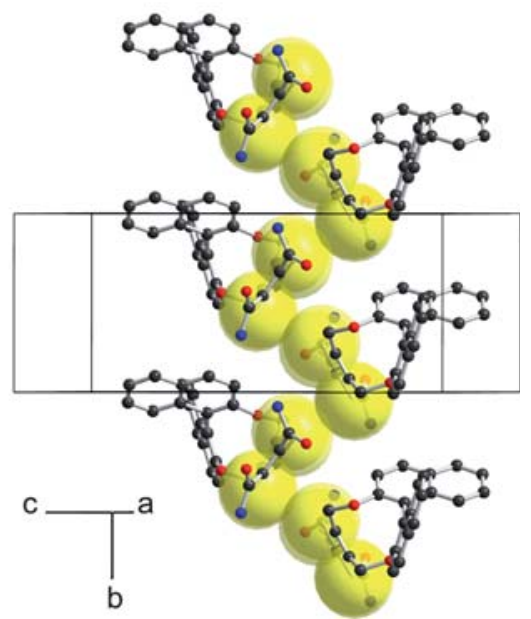

Fig. 10 Views of the chiral chains of TTF running along the $2_{1}$ axis along $b$, (a) in $(R)$-2 $\cdot(\mathrm{THF})_{2}$ and (b) in $(S)-2 \cdot(\mathrm{DMSO})_{2}$. Note that the two chains are related by mirror plane. The sulfur atoms are drawn at van der Waals radius $(1.8 \AA$ ). 
Table 4 Intermolecular $\mathrm{S} \cdots \mathrm{S}$ contacts between $(R)$-2 or $(S)$-2 molecules interacting along the $2_{1}$ axis in $(R)-\mathbf{2} \cdot(\mathrm{THF})_{2}$ or $(S)-\mathbf{2} \cdot(\mathrm{DMSO})_{2}$

\begin{tabular}{lllll}
\hline$(R)-\mathbf{2} \cdot(\mathrm{THF})_{2}$ & & & $(S)-\mathbf{2} \cdot(\mathrm{DMSO})_{2}$ & \\
\cline { 1 - 2 } Interaction & $\mathrm{S} \cdots \mathrm{S} / \AA$ & & Interaction & $\mathrm{S} \cdots \mathrm{S} / \AA$ \\
\hline $\mathrm{S} 1 \cdots \mathrm{S} 3^{a}$ & $3.525(10)$ & & $\mathrm{S} 1 \cdots \mathrm{S} 3^{b}$ & $3.606(7)$ \\
$\mathrm{S} 1 \cdots \mathrm{S} 2^{a}$ & $3.643(9)$ & & $\mathrm{S} 1 \cdots \mathrm{S} 2^{b}$ & $3.665(7)$ \\
$\mathrm{S} 2 \cdots \mathrm{S} 4^{b}$ & $3.584(12)$ & $\mathrm{S} 2 \cdots \mathrm{S} 4^{a}$ & $3.632(8)$ \\
${ }^{a} 2-x,-0.5+y, 1-z \cdot{ }^{b} 2-x, 0.5+y, 1-z$. & \\
\hline
\end{tabular}

white crystals $(0.9 \mathrm{~g}, 66 \%)$ after recrystallization from $\mathrm{CH}_{2} \mathrm{Cl}_{2} /-$ petroleum ether; $\mathrm{mp}=280{ }^{\circ} \mathrm{C} .{ }^{1} \mathrm{H}$ NMR $\left(300 \mathrm{MHz}, \mathrm{CDCl}_{3}\right)$ $\delta 7.9(2 \mathrm{H}, \mathrm{d}, J=8.7 \mathrm{~Hz}), 7.82(2 \mathrm{H}, \mathrm{d}, J=8.1 \mathrm{~Hz}), 7.34(2 \mathrm{H}, \mathrm{d}$, $J=8.9 \mathrm{~Hz}$ ), 7.33-7.28 (2H, m), 7.20-7.14 (2H, m), 7.10-7.07 $(2 \mathrm{H}, \mathrm{m}), 4.97(4 \mathrm{H}, \mathrm{s}) .{ }^{13} \mathrm{C} \mathrm{NMR}\left(300 \mathrm{MHz}, \mathrm{CDCl}_{3}\right) \delta 198.45$, $153.65,133.61,130.30,129.98,129.66,128.19,126.81,126.04$, 124.65, 122.35, 117.28, 64.62. MS (MALDI-TOF) $\mathrm{m} / \mathrm{z} 428.7$ $\left(\mathrm{M}^{+}\right)$. Anal. Calc. for $\mathrm{C}_{25} \mathrm{H}_{16} \mathrm{O}_{3} \mathrm{~S}_{2}: \mathrm{C}, 70.07 ; \mathrm{H}, 3.76$. Found: $\mathrm{C}$, $69.91 ; \mathrm{H}, 3.55 \%$.

\section{Enantiopure 1,3-dithiole-2-one $(R)-3 b$}

To a solution of enantiopure $(R)-3 \mathbf{a}(2 \mathrm{~g}, 4.498 \mathrm{mmol})$ in $\mathrm{CHCl}_{3}$ $(25 \mathrm{~mL})$ under nitrogen was added a solution of mercuric acetate ( $3.6 \mathrm{~g}, 2.5$ equiv.) in glacial acetic acid $(35 \mathrm{~mL})$. After a few min, the solution turned into a milky green and changed to white over $15 \mathrm{~min}$. After stirring at r.t. for $4 \mathrm{~h}$, the precipitate was filtered using hyflo and washed thoroughly with $\mathrm{CH}_{2} \mathrm{Cl}_{2}$. The organic layer was washed twice with $1 \mathrm{M} \mathrm{NaHCO}_{3}$ solution $(400 \mathrm{~mL})$, dried $\left(\mathrm{MgSO}_{4}\right)$ and evaporated. Purification by column chromatography on silica gel $\left(\mathrm{CH}_{2} \mathrm{Cl}_{2}\right)$ gave $(R)-\mathbf{3 b}$ as white crystals $(1.4 \mathrm{~g}, 73 \%)$ after recrystallization from $\mathrm{CH}_{2} \mathrm{Cl}_{2}$ - petroleum ether; $\mathrm{mp}=256{ }^{\circ} \mathrm{C} ;[\alpha]_{\mathrm{D}}=-60\left(c 0.05, \mathrm{CH}_{2} \mathrm{Cl}_{2}\right) .{ }^{1} \mathrm{H}$ NMR $(300$ $\left.\mathrm{MHz}, \mathrm{CDCl}_{3}\right) \delta 7.98(2 \mathrm{H}, \mathrm{d}, J=8.7 \mathrm{~Hz}), 7.9(2 \mathrm{H}, \mathrm{d}, J=8.1 \mathrm{~Hz})$, $7.42(2 \mathrm{H}, \mathrm{d}, J=8.9 \mathrm{~Hz}), 7.42-7.37(2 \mathrm{H}, \mathrm{m}), 7.28-7.23(2 \mathrm{H}, \mathrm{m})$, 7.19-7.16 (2H, m), $5.05(4 \mathrm{H}, \mathrm{s}) .{ }^{13} \mathrm{C}$ NMR $\left(300 \mathrm{MHz}, \mathrm{CDCl}_{3}\right)$ $\delta 189.46,153.71,133.64,130.32,129.99,129.66,128.22,126.83$, 126.06, 124.67, 122.38, 117;31, 64.59. MS (MALDI-TOF) $\mathrm{m} / \mathrm{z}$ $428.76\left(\mathrm{M}^{+}\right)$. Anal. Calc. for $\mathrm{C}_{25} \mathrm{H}_{16} \mathrm{O}_{3} \mathrm{~S}_{2}$ : C, 70.07; H, 3.76. Found: C, 69.86; H, 3.64\%.

\section{Enantiopure 1,3-dithiole-2-one (S)-3b}

To a solution of enantiopure $(S)-3 a(1.3 \mathrm{~g}, 2.92 \mathrm{mmol})$ in $\mathrm{CHCl}_{3}$ $(15 \mathrm{~mL})$ under nitrogen was added a solution of mercuric acetate ( $2.34 \mathrm{~g}, 2.5$ equiv.) in glacial acetic acid $(25 \mathrm{~mL})$. After a few min, the solution turned into a milky green and changed to white over $15 \mathrm{~min}$. After stirring at r.t. for $4 \mathrm{~h}$, the precipitate was filtered using hyflo and washed thoroughly with $\mathrm{CH}_{2} \mathrm{Cl}_{2}$. The organic layer was washed twice with $1 \mathrm{M} \mathrm{NaHCO}_{3}$ solution $(250 \mathrm{~mL})$, dried $\left(\mathrm{MgSO}_{4}\right)$ and evaporated. Purification by column chromatography on silica gel $\left(\mathrm{CH}_{2} \mathrm{Cl}_{2}\right)$ gave the dithiolone as white crystals $(1 \mathrm{~g}, 80 \%)$ after recrystallization from $\mathrm{CH}_{2} \mathrm{Cl}_{2}$-petroleum ether; $\mathrm{mp}=254{ }^{\circ} \mathrm{C} ;[\alpha]_{\mathrm{D}}=+62\left(c 0.05, \mathrm{CH}_{2} \mathrm{Cl}_{2}\right) .{ }^{1} \mathrm{H} \mathrm{NMR}$ $\left(300 \mathrm{MHz}, \mathrm{CDCl}_{3}\right) \delta 8.00(2 \mathrm{H}, \mathrm{d}, J=8.9 \mathrm{~Hz}), 7.92(2 \mathrm{H}, \mathrm{d}, J=8.1$ $\mathrm{Hz}), 7.43(2 \mathrm{H}, \mathrm{d}, J=8.9 \mathrm{~Hz}), 7.44-7.38(2 \mathrm{H}, \mathrm{m}), 7.30-7.20(4 \mathrm{H}$, m), $4.98(4 \mathrm{H}, \mathrm{s}) .{ }^{1} \mathrm{H}$ NMR $\left(300 \mathrm{MHz}, \mathrm{CD}_{2} \mathrm{Cl}_{2}\right) \delta 8.05(2 \mathrm{H}, \mathrm{d}, J=$
$8.9 \mathrm{~Hz}), 7.97(2 \mathrm{H}, \mathrm{d}, J=8.1 \mathrm{~Hz}), 7.49(2 \mathrm{H}, \mathrm{d}, J=8.9 \mathrm{~Hz}), 7.47-$ $7.42(2 \mathrm{H}, \mathrm{m}), 7.31-7.26(2 \mathrm{H}, \mathrm{m}), 7.19$ (2H, d, $J=8.6 \mathrm{~Hz}), 5.05$ $(4 \mathrm{H}, \mathrm{s}) .{ }^{13} \mathrm{C}$ NMR $\left(300 \mathrm{MHz}, \mathrm{CDCl}_{3}\right) \delta 189.52,153.74,133.65$, $130.32,130.01,129.65,128.26,126.86,126.08,124.69,122.37$, 117.31, 64.57. $\left.{ }^{13} \mathrm{C} \mathrm{NMR} \mathrm{(300} \mathrm{MHz,} \mathrm{CD}_{2} \mathrm{Cl}_{2}\right) \delta 189.84,154.29$, $133.99,130.71,130.39$, 130.10, 128.67, 127.16, 126.22, 125.06, 122.68, 117.91, 65.07. MS (MALDI-TOF) $\mathrm{m} / \mathrm{z} 428.7\left(\mathrm{M}^{+}\right)$. Anal. Calc. for $\mathrm{C}_{25} \mathrm{H}_{16} \mathrm{O}_{3} \mathrm{~S}_{2}$ : C, 70.07; H, 3.76. Found: C, 69.45; H, $3.86 \%$.

\section{Racemic diester $(R, S)-5$}

A mixture of 4,5-bis(carboxymethyl)-1,3-dithiole-2-thione (2.81 $\mathrm{g}, 11 \mathrm{mmol}, 5$ equiv. $)$ and racemic $(R, S)-3 \mathrm{a}(1 \mathrm{~g}, 2.249 \mathrm{mmol})$ was heated in $\mathrm{P}(\mathrm{OMe})_{3}(100 \mathrm{~mL})$ at $135^{\circ} \mathrm{C}$ under $\mathrm{N}_{2}$ for $4 \mathrm{~h}$ to give a red solution. $\mathrm{P}(\mathrm{OMe})_{3}$ was removed in vacuo and the residue purified by chromatography $\left(\mathrm{SiO}_{2}, \mathrm{CH}_{2} \mathrm{Cl}_{2}\right.$-petroleum ether 2 : 1). Recrystallisation from $\mathrm{CH}_{2} \mathrm{Cl}_{2}$-petroleum ether afforded the racemic diester $(R, S)-5$ as red crystals $(0.55 \mathrm{~g}, 40 \%)$; mp 228 ${ }^{\circ} \mathrm{C}$. ${ }^{1} \mathrm{H}$ NMR $\left(300 \mathrm{MHz}, \mathrm{CD}_{2} \mathrm{Cl}_{2}\right) \delta 7.91(2 \mathrm{H}, \mathrm{d}, J=9 \mathrm{~Hz}), 7.82$ $(2 \mathrm{H}, \mathrm{d}, J=8.1 \mathrm{~Hz}), 7.36(2 \mathrm{H}, \mathrm{d}, J=8.7 \mathrm{~Hz}), 7.29(2 \mathrm{H}, \mathrm{t}, J=6.9$ $\mathrm{Hz}), 7.14(2 \mathrm{H}, \mathrm{t}, J=6.9 \mathrm{~Hz}), 7.01(2 \mathrm{H}, \mathrm{d}, J=8.4 \mathrm{~Hz}), 4.77(4 \mathrm{H}$, s), $3.71(6 \mathrm{H}, \mathrm{s}) \mathrm{ppm} .{ }^{13} \mathrm{C} \mathrm{NMR}\left(300 \mathrm{MHz}, \mathrm{CD}_{2} \mathrm{Cl}_{2}\right) \delta 160.26$, $154.39,133.95,132.46,130.97,130.65,130.19,128.58,126.98$, $126.16,124.89,122.65,118.01,113.39,104.95,65.07$ ppm. MS (MALDI-TOF) $m / z$ 629.91 (M+ $\mathrm{M}^{+}$. Anal. Calc. for $\mathrm{C}_{32} \mathrm{H}_{22} \mathrm{O}_{6} \mathrm{~S}_{4}: \mathrm{C}$, 60.93 ; H, 3.52. Found: C, 60.99; H, 3,42\%.

\section{Enantiopure diester $(R)-5$}

4,5-Bis(carboxymethyl)-1,3-dithiole-2-thione (526 g, $22.4 \mathrm{mmol}$, 5 equiv.) and the enantiopure $(R)-3 a(2 \mathrm{~g}, 4.49 \mathrm{mmol}, 1$ equiv.) were heated in a solution of $\mathrm{P}(\mathrm{OMe})_{3}(30 \mathrm{~mL})$ and toluene $(30 \mathrm{~mL})$ at $135{ }^{\circ} \mathrm{C}$ under $\mathrm{N}_{2}$ for $4 \mathrm{~h}$ to give a red solution. Trimethyl phosphite was removed in vacuo and the residue purified by chromatography $\left(\mathrm{SiO}_{2}, \mathrm{CH}_{2} \mathrm{Cl}_{2}\right.$-petroleum ether 2 : 1). Recrystallization from $\mathrm{CH}_{2} \mathrm{Cl}_{2}$-petroleum ether afforded the enantiopure $(R)-5$ as red crystals $(1.3 \mathrm{~g}, 46 \%) ; \mathrm{mp}=210{ }^{\circ} \mathrm{C}$; $[\alpha]_{\mathrm{D}}=+300\left(c 0.05, \mathrm{CH}_{2} \mathrm{Cl}_{2}\right) .{ }^{1} \mathrm{H} \mathrm{NMR}\left(300 \mathrm{MHz}, \mathrm{CDCl}_{3}\right)$ $\delta 8.04(2 \mathrm{H}, \mathrm{d}, J=9 \mathrm{~Hz}), 7.95(2 \mathrm{H}, \mathrm{d}, J=8.1 \mathrm{~Hz}), 7.48(2 \mathrm{H}, \mathrm{d}$, $J=9 \mathrm{~Hz}), 7.42(2 \mathrm{H}, \mathrm{td}, J=6.9 \mathrm{~Hz}), 7.26(2 \mathrm{H}, \mathrm{td}, J=6.9 \mathrm{~Hz})$, $7.16(2 \mathrm{H}, \mathrm{d}, J=8.1 \mathrm{~Hz}), 4.87(4 \mathrm{H}, \mathrm{s}), 3.84(6 \mathrm{H}, \mathrm{s}) \mathrm{ppm} .{ }^{13} \mathrm{C}$ NMR (300 MHz, $\left.\mathrm{CD}_{2} \mathrm{Cl}_{2}\right) \delta 160.27,154.41,133.96,132.49$, $130.97,130.65,130.21,128.60,127.01,126.18,124.91,122.65$, $118.02,113.43,104.90,65.06 \mathrm{ppm}$. MS (MALDI-TOF) $\mathrm{m} / \mathrm{z}$ $630.09\left(\mathrm{M}^{+}\right)$. Anal. Calc. for $\mathrm{C}_{32} \mathrm{H}_{22} \mathrm{O}_{6} \mathrm{~S}_{4}$ : C, 60.93; H, 3.52. Found: C, 60.83; H, 3.48\%.

\section{Enantiopure diester $(S)-5$}

4,5-Bis(carboxymethyl)-1,3-dithiole-2-thione (1.97 g, $7.87 \mathrm{mmol}$, 5 équiv.) and $(S)-3 \mathrm{a}(0.7 \mathrm{~g}, 1.57 \mathrm{mmol}, 1$ equiv. $)$ were heated in a solution of $\mathrm{P}(\mathrm{OMe})_{3}(10 \mathrm{~mL})$ at $135^{\circ} \mathrm{C}$ under $\mathrm{N}_{2}$ for $4 \mathrm{~h}$ to give a red solution. Trimethylphosphite was removed in vacuo and the residue purified by chromatography $\left(\mathrm{SiO}_{2}, \mathrm{CH}_{2} \mathrm{Cl}_{2}\right.$-petroleum ether 2 : 1). Recrystallization from $\mathrm{CH}_{2} \mathrm{Cl}_{2}$-ethanol afforded $(S)$ 5 as red crystals $(0.45 \mathrm{~g}, 46 \%) ; \mathrm{mp}=212^{\circ} \mathrm{C} ;[\alpha]_{\mathrm{D}}=-290(c 0.05$, $\left.\mathrm{CH}_{2} \mathrm{Cl}_{2}\right) .{ }^{1} \mathrm{H} \mathrm{NMR}\left(300 \mathrm{~Hz}, \mathrm{CD}_{2} \mathrm{Cl}_{2}\right) \delta 7.9(2 \mathrm{H}, \mathrm{d}, J=9 \mathrm{~Hz}), 7.81$ $(2 \mathrm{H}, \mathrm{d}, J=8.1 \mathrm{~Hz}), 7.34(2 \mathrm{H}, \mathrm{d}, J=9 \mathrm{~Hz}), 7.31-7.25(2 \mathrm{H}, \mathrm{m})$, 7.15-7.10 (2H, m), $7.01(2 \mathrm{H}, \mathrm{d}, J=8.4 \mathrm{~Hz}), 4.74(4 \mathrm{H}, \mathrm{s}), 3.70$ 
Table 5 Crystallographic data

\begin{tabular}{|c|c|c|c|c|c|c|c|c|c|c|}
\hline & $\begin{array}{l}{[(R)-\mathbf{3 a}] \cdot} \\
(\mathrm{tol})_{0.5}\end{array}$ & $\begin{array}{l}{[(S)-\mathbf{3 a}] \cdot} \\
(\mathrm{tol})_{0.5}\end{array}$ & $(R)-\mathbf{3 b}$ & $(S)-\mathbf{3 b}$ & $(R, S)-\mathbf{3 b}$ & $(R, S)-\mathbf{5}$ & $(R)-5$ & $\begin{array}{l}(R)-\mathbf{2} \cdot \\
(\mathrm{THF})_{0.5}\end{array}$ & $\begin{array}{l}(R)-\mathbf{2} \\
(\mathrm{THF})_{2}\end{array}$ & $\begin{array}{l}(S)-\mathbf{2} \\
(\mathrm{DMSO})_{2}\end{array}$ \\
\hline Formula & $\mathrm{C}_{57} \mathrm{H}_{40} \mathrm{O}_{4} \mathrm{~S}_{6}$ & ${ }_{6} \mathrm{C}_{57} \mathrm{H}_{40} \mathrm{O}_{4} \mathrm{~S}_{6}$ & ${ }_{6} \mathrm{C}_{25} \mathrm{H}_{16} \mathrm{O}_{3} \mathrm{~S}_{2}$ & ${ }_{2} \mathrm{C}_{25} \mathrm{H}_{16} \mathrm{O}_{3} \mathrm{~S}_{2}$ & ${ }_{2} \mathrm{C}_{25} \mathrm{H}_{16} \mathrm{O}_{3} \mathrm{~S}_{2}$ & $\mathrm{C}_{32} \mathrm{H}_{22} \mathrm{O}_{6} \mathrm{~S}_{4}$ & ${ }_{4} \mathrm{C}_{32} \mathrm{H}_{22} \mathrm{O}_{6} \mathrm{~S}_{4}$ & ${ }_{7} \mathrm{C}_{64} \mathrm{H}_{48} \mathrm{~N}_{4} \mathrm{O}_{9} \mathrm{~S}$ & $\mathrm{C}_{38} \mathrm{H}_{36} \mathrm{~N}_{2} \mathrm{O}_{6} \mathrm{~S}_{4}$ & ${ }_{1} \mathrm{C}_{34} \mathrm{H}_{32} \mathrm{~N}_{2} \mathrm{O}_{6} \mathrm{~S}_{6}$ \\
\hline $\begin{array}{l}\text { Crystal } \\
\text { system }\end{array}$ & Trigonal & Trigonal & Monoclinic & Monoclinic & Orthorhombic & Triclinic & Monoclinic & Monoclinic & Monoclinic & Monoclinic \\
\hline $\begin{array}{l}\text { Space } \\
\text { group }\end{array}$ & $P 3_{1}$ & $\mathrm{P}_{2}$ & $P 2_{1}$ & $P 2_{1}$ & $P b c a$ & $P \overline{1}$ & $C 2$ & $P 2_{1}$ & $P 2_{1}$ & $P 2_{1}$ \\
\hline$b / \AA$ & 11.2192 & 11.2067 & $11.7236(18)$ & $11.7306(7)$ & $8.5699(17)$ & 11.193(3) & $7.425(2)$ & $37.71(2)$ & $8.203(5)$ & $8.1962(4)$ \\
\hline$c / \AA$ & $32.2233(18)$ & $32.115(2)$ & $20.177(3)$ & $20.1726(9)$ & $41.840(8)$ & $17.395(4)$ & $11.354(5)$ & $10.367(4)$ & $19.741(5)$ & $19.7771(8)$ \\
\hline$\alpha /^{\circ}$ & 90.0 & 90.0 & 90.0 & 90.0 & 90.0 & $72.117(12)$ & 90.0 & 90.0 & 90.0 & 90.0 \\
\hline$\beta /^{\circ}$ & 90.0 & 90.0 & $91.735(8)$ & $91.661(6)$ & 90.0 & $88.424(13)$ & $105.52(3)$ & $103.31(4)$ & $106.302(5)$ & $104.035(6)$ \\
\hline$\gamma /{ }^{\circ}$ & 120.0 & 120.0 & 90.0 & 90.0 & 90.0 & $71.483(13)$ & 90.0 & 90.0 & 90.0 & 90.0 \\
\hline$V / \AA^{3}$ & $3512.6(3)$ & $3493.0(3)$ & 2004.5(4) & 2005.39(19) & $4009.1(14)$ & $1371.3(6)$ & $2843.5(18)$ & $3003(3)$ & 1778.7(14) & $1796.85(15)$ \\
\hline$Z$ & 3 & 3 & 4 & 4 & 8 & 2 & 4 & 2 & 2 & 2 \\
\hline Indep. data & 10482 & 10017 & 8916 & 8531 & 4552 & 6195 & 5732 & 9137 & 6754 & 7744 \\
\hline$R_{\mathrm{int}}$ & 0.0415 & 0.0425 & 0.0535 & 0.0246 & 0.0715 & 0.0418 & 0.0482 & 0.0763 & 0.1013 & 0.0579 \\
\hline $\begin{array}{l}\text { Obs. data } \\
\quad(I>2 \sigma(I))\end{array}$ & 10371 & 8941 & 5570 & 6523 & 2404 & 5135 & 4944 & 4129 & 3626 & 5328 \\
\hline $\begin{array}{l}\text { Param. } \\
\text { refined }\end{array}$ & 604 & 605 & 531 & 536 & 271 & 379 & 381 & 766 & 451 & 447 \\
\hline$R(F)$ & 0.0349 & 0.0864 & 0.0725 & 0.0677 & 0.0418 & 0.0352 & 0.0594 & 0.0741 & 0.0697 & 0.0525 \\
\hline$w R\left(F^{2}\right)$ & 0.082 & 0.2246 & 0.2005 & 0.1947 & 0.1612 & 0.0972 & 0.1237 & 0.0999 & 0.1577 & 0.1208 \\
\hline $\begin{array}{l}\text { Flack } \\
\text { param. }\end{array}$ & $0.01(4)$ & $0.03(11)$ & $-0.04(11)$ & $-0.02(10)$ & - & - & $0.002(9)$ & $0.03(7)$ & $-0.02(12)$ & $0.06(8)$ \\
\hline$\Delta \rho_{\max } / \mathrm{e} \AA_{\circ}^{\circ}$ & +0.335 & +0.658 & 1.446 & 2.000 & 0.381 & +0.38 & +0.71 & +0.272 & +0.400 & +0.42 \\
\hline$\Delta \rho_{\min } / \mathrm{e} \AA^{-3}$ & -0.219 & -0.526 & -0.917 & -0.997 & -0.366 & -0.33 & -0.35 & -0.256 & -0.479 & -0.423 \\
\hline
\end{tabular}

$(6 \mathrm{H}, \mathrm{s}) .{ }^{13} \mathrm{C} \mathrm{NMR}\left(300 \mathrm{MHz}, \mathrm{CD}_{2} \mathrm{Cl}_{2}\right) \delta 160.27,154.39,133.94$, $132.47,130.64,130.21,128.60,127.01,126.18,124.91,122.63$, $118.00,113.42,104.90,65.05,53.73$. MS (MALDI-TOF) $\mathrm{m} / \mathrm{z}$ $630.2\left(\mathrm{M}^{+}\right)$. Anal. Calc. for $\mathrm{C}_{32} \mathrm{H}_{22} \mathrm{O}_{6} \mathrm{~S}_{4}: \mathrm{C}, 60.93 ; \mathrm{H}, 3.52$. Found: C, 61.02; H, 3.51\%.

\section{Racemic bisamide $(R, S)-2$}

A solution of the racemic diester $(R, S)-5(350 \mathrm{mg}, 0.554 \mathrm{mmol})$ in THF $(70 \mathrm{~mL})$ was reacted with an excess of ammonia in aqueous solution $(15 \mathrm{~mL}, 25 \% \mathrm{w} / \mathrm{w})$. After stirring for $24 \mathrm{~h}$ at room temperature, the resulting precipitate was filtered off and washed with water. After column chromatography (silica gel, THF- $\mathrm{CH}_{2} \mathrm{Cl}_{2}$ 1:3), and solvent evaporation, the residue was recrystallised from $\mathrm{THF}$ and pentane to afford the racemic diamide $(R, S)-2$ as black crystals $(250 \mathrm{mg}, 79 \%) ; \mathrm{mp}=208{ }^{\circ} \mathrm{C}$. IR (ATR) 3250, $3171\left(\mathrm{NH}_{2}\right), 1690,1658(\mathrm{C}=\mathrm{O}) \mathrm{cm}^{-1} \cdot{ }^{1} \mathrm{H}$ NMR (300 MHz, DMSO) $\delta 8.27\left(2 \mathrm{H}, \mathrm{s}, \mathrm{NH}_{2}\right), 8.07(2 \mathrm{H}, \mathrm{d}, J=$ $9 \mathrm{~Hz}), 8.03\left(2 \mathrm{H}, \mathrm{s}, \mathrm{NH}_{2}\right), 7.97(2 \mathrm{H}, \mathrm{d}, J=8.1 \mathrm{~Hz}), 7.66(2 \mathrm{H}, \mathrm{d}$, $J=9 \mathrm{~Hz}), 7.38(2 \mathrm{H}, \mathrm{t}, J=7.2 \mathrm{~Hz}), 7.25(2 \mathrm{H}, \mathrm{t}, J=7.2 \mathrm{~Hz})$, $6.96(2 \mathrm{H}, \mathrm{d}, J=8.4), 5.02(4 \mathrm{H}, \mathrm{s}) \mathrm{ppm} .{ }^{13} \mathrm{C} \mathrm{NMR}(300 \mathrm{MHz}$, DMSO) $\delta 160.64,154.04,133.35,132.90,130.58,129.65$, $129.57,128.25,126.51,125.19,124.17,121.27,118.03,110.25$, 103.54, 66.98, 63.95, 25.08 ppm. MS (MALDI-TOF) $\mathrm{m} / \mathrm{z}$ $599.87\left(\mathrm{M}^{+}\right)$. Anal. Calc. for $\mathrm{C}_{30} \mathrm{H}_{20} \mathrm{~N}_{2} \mathrm{O}_{4} \mathrm{~S}_{4}$ : C, 59.98; H, 3.36 . Found: C, 59.68; H, 3.39\%.

\section{Enantiopure bisamide $(R)-2$}

A solution of enantiopure diester $(R)-5\left(500 \mathrm{mg}, 7.910^{-4} \mathrm{mmol}\right)$ in $\mathrm{CH}_{3} \mathrm{CN}(100 \mathrm{~mL})$ was reacted with an excess of ammonia in aqueous solution $(20 \mathrm{~mL}, 25 \% \mathrm{w} / \mathrm{w})$. After stirring for $24 \mathrm{~h}$ at room temperature, the resulting precipitate was filtered off and washed with water. After column chromatography (silica gel, THF- $\mathrm{CH}_{2} \mathrm{Cl}_{2}$ 1:3), and solvent evaporation, crystals were obtained from a solution of THF by diffusion of pentane vapours. Two distinct crystalline phases were obtained, orange crystals at the bottom of the THF beaker, and dark red crystals at the pentane-enriched THF surface. their formulation has been deduced from the X-ray crystal structure analysis, the orange crystals as $(R)-\mathbf{2} \cdot(\mathrm{THF})_{2}$, the dark red ones as $(R)-\mathbf{2} \cdot(\mathrm{THF})_{0.5}$ (total weight: $380 \mathrm{mg}, 79 \%) ;[\alpha]_{\mathrm{D}}=+310\left(c 0.05, \mathrm{CH}_{2} \mathrm{Cl}_{2}\right) .{ }^{1} \mathrm{H}$ NMR (300 MHz, DMSO) $\delta 8,29\left(2 \mathrm{H}, \mathrm{s}, \mathrm{NH}_{2}\right), 8.07$ (2H, d, $J=8.1$ $\mathrm{Hz}), 8.05\left(2 \mathrm{H}, \mathrm{s}, \mathrm{NH}_{2}\right), 7.97(2 \mathrm{H}, \mathrm{d}, J=8.1 \mathrm{~Hz}), 7.66(2 \mathrm{H}, \mathrm{d}, J=9$ $\mathrm{Hz}), 7.38(2 \mathrm{H}, \mathrm{t}, J=7.8 \mathrm{~Hz}), 7.24(2 \mathrm{H}, \mathrm{d}, J=7.5 \mathrm{~Hz}), 6.96(2 \mathrm{H}, \mathrm{d}$, $J=8.4 \mathrm{~Hz}), 5.02(4 \mathrm{H}, \mathrm{s}) \mathrm{ppm} .{ }^{13} \mathrm{C}$ NMR (300 MHz, DMSO) $\delta 160.64,154.03,133.35,132.87,130.57,129.64,129.58,128.25$, 126.51, 125.19, 124.17, 121.21, 118.01, 110.24, 103.48, 66.97, 63.92, $25.08 \mathrm{ppm}$. MS (MALDI-TOF) $\mathrm{m} / \mathrm{z} 600.06\left(\mathrm{M}^{+}\right)$. The THF solvates were dried at $80{ }^{\circ} \mathrm{C}$ for one week before analysis. Anal. Calc. for $\mathrm{C}_{30} \mathrm{H}_{20} \mathrm{~N}_{2} \mathrm{O}_{4} \mathrm{~S}_{4}$ : C, 59.98; H, 3.36. Found: C, 59.94; H, 3.33; mp $212{ }^{\circ} \mathrm{C}$. IR (ATR) for $(R)-2 \cdot(\mathrm{THF})_{2}: 3312,3144\left(\mathrm{NH}_{2}\right)$, $1697,1663(\mathrm{C}=\mathrm{O}) \mathrm{cm}^{-1}$; IR $(\mathrm{ATR})$ for $(R)-2 \cdot(\mathrm{THF})_{0.5}: 3263,3132$ $\left(\mathrm{NH}_{2}\right), 1690,1655(\mathrm{C}=\mathrm{O}) \mathrm{cm}^{-1}$. 


\section{Enantiopure bisamide $(S)-2$}

A solution of $(S)-5(150 \mathrm{mg}, 0.237 \mathrm{mmol})$ in $\mathrm{CH}_{3} \mathrm{CN}(25 \mathrm{~mL})$ was reacted with excess of ammonia in aqueous solution $(5 \mathrm{~mL}, 25 \%$ $\mathrm{w} / \mathrm{w})$. After stirring for $24 \mathrm{~h}$ at room temperature, the resulting precipitate was filtered off and washed with water. After column chromatography (silica gel, THF- $\mathrm{CH}_{2} \mathrm{Cl}_{2} 1: 3$ ), and solvent evaporation, the residue was recrystallised from DMSO to afford the title compound as a DMSO solvate, $(S)-\mathbf{2} \cdot \mathrm{DMSO}$ as red crystals $(110 \mathrm{mg}, 78 \%) ;[\alpha]_{\mathrm{D}}=-295\left(c 0.05, \mathrm{CH}_{2} \mathrm{Cl}_{2}\right) ; \mathrm{mp}=$ $212^{\circ} \mathrm{C}$. IR (ATR) 3459, $3254\left(\mathrm{NH}_{2}\right), 1689,1657(\mathrm{C}=\mathrm{O}) \mathrm{cm}^{-1} \cdot{ }^{1} \mathrm{H}$ NMR (300 MHz, DMSO) $\delta 8.29\left(2 \mathrm{H}, \mathrm{s}, \mathrm{NH}_{2}\right), 8.07(2 \mathrm{H}, \mathrm{d}, J=$ $8.1 \mathrm{~Hz}), 8.05\left(2 \mathrm{H}, \mathrm{s}, \mathrm{NH}_{2}\right), 7.97(2 \mathrm{H}, \mathrm{d}, J=8.1 \mathrm{~Hz}), 7.66(2 \mathrm{H}, \mathrm{d}$, $J=9 \mathrm{~Hz}), 7.38(2 \mathrm{H}, \mathrm{t}, J=7.35 \mathrm{~Hz}), 7.24(2 \mathrm{H}, \mathrm{t}, J=7.5 \mathrm{~Hz}), 6.96$ $(2 \mathrm{H}, \mathrm{d}, J=8.7 \mathrm{~Hz}), 5.02(4 \mathrm{H}, \mathrm{s}) \mathrm{ppm} .{ }^{13} \mathrm{C} \mathrm{NMR}(300 \mathrm{MHz}$, DMSO) $\delta 160.64,154.03,133.35,132.88,130.57,129.64,129.58$, $128.26,126.52,125.19,124.18,121.24,118.02,110.26,103.50$, $63.93 \mathrm{ppm}$. MS (MALDI-TOF) $\mathrm{m} / \mathrm{z} 600.06\left(\mathrm{M}^{+}\right)$. The DMSO solvate was dried at $80{ }^{\circ} \mathrm{C}$ for one week before analysis. Anal. Calc. for $\mathrm{C}_{30} \mathrm{H}_{20} \mathrm{~N}_{2} \mathrm{O}_{4} \mathrm{~S}_{4}$ : C, 59.98; H, 3.36. Found: C, 60.01; H, 3.84\%.

\section{Crystallography}

Experimental data and refinement results are given in Table 5. Data were collected on a APEX II Brucker AXS diffractometer with Mo-K $\alpha$ radiation $(\lambda=0.71073 \AA)$. Structures were solved by direct methods (SHELXS97 $7^{36}$ or SIR92) ${ }^{37}$ and refined (SHELXL-97) $^{36}$ by full-matrix least-squares methods as implemented in the WinGX software package. ${ }^{38}$ An empirical absorption (multi-scan) correction was applied. Hydrogen atoms were introduced at calculated positions (riding model) included in structure factor calculation but not refined. The quality of the crystal structures of $(R)-\mathbf{2} \cdot(\mathrm{THF})_{0.5}$ and $(R)-\mathbf{2} \cdot(\mathrm{THF})_{2}$ was affected by solvent evaporation.

\section{Acknowledgements}

Financial support from ANR (Paris) under grant number BLAN08-3_317277 is acknowledged.

\section{References}

1 (a) E. Coronado and P. Day, Chem. Rev., 2004, 104, 5419; (b) E. Coronado and J. R. Galan-Mascaros, J. Mater. Chem., 2005, 15, 66.

2 (a) V. Krstic, S. Roth, M. Burghard, K. Kern and G. L. J. A. Rikken, J. Chem. Phys., 2002, 117, 11315; (b) V. Krstic and G. L. J. A. Rikken, Chem. Phys. Lett., 2002, 364, 51.

3 N. Avarvari and J. Wallis, J. Mater. Chem., 2009, 19, 4061-4076, and references therein.

4 E. Coronado, J. R. Galan-Mascaros, C. J. Gomez-Garcia, A. MurciaMartinez and E. Canadell, Inorg. Chem., 2004, 43, 8072-8077.

5 M. Brezgunova, K.-S. Shin, O. Jeannin, P. Auban-Senzier and M. Fourmigué, Chem. Commun., 2010, 46, 3926.

6 J. D. Dunitz, A. Karrer and J. D. Wallis, Helv. Chim. Acta, 1986, 69, 69.

7 (a) C. Réthoré, N. Avarvari, E. Canadell, P. Auban-Senzier and

M. Fourmigué, J. Am. Chem. Soc., 2005, 127, 5748; (b)

A. M. Madalan, C. Réthoré, M. Fourmigué, E. Canadell,

E. B. Lopes, M. Almeida, P. Auban-Senzier and N. Avarvari, Chem.-Eur. J., 2010, 16, 528.

8 L. Pu, Chem. Rev., 1998, 98, 2405.

9 R. Gómez, J. L. Segura and N. Martın, J. Org. Chem., 2000, 65, 7566.

10 Y. Zhou, D. Zhang, L. Zhu, Z. Shuai and D. Zhu, J. Org. Chem., 2006, 71, 2123.
$11 \mathrm{H}$. Wu, D. Zhang and D. Zhu, Tetrahedron Lett., 2007, 48, 8951.

12 A. Saad, F. Barrière, E. Levillain, O. Jeannin and M. Fourmigué, Chem.-Eur. J., 2010, DOI: 10.1002/chem.200902050, in press.

13 R. E. Dickerson, Science, 1982, 216, 475.

14 K. Okuyama, S. Arnott, M. Takanyanagi and M. Kakudo, J. Mol. Biol., 1981, 152, 427.

15 H. M. Warrick and J. A. Spudich, Annu. Rev. Cell Biol., 1987, 3, 379.

16 E. Kolomiets, V. Berl and J.-M. Lehn, Chem.-Eur. J., 2007, 13, 5466, and references therein.

17 Y. Hase, K. Nagia, H. Iida, K. Maeda, N. Ochi, K. Sawabe, K. Sakajiri, K. Okoshi and E. Yashima, J. Am. Chem. Soc., 2009, 131, 10719.

18 N. A. J. M. Sommerdijk, P. J. J. A. Buynsters, H. Akdemir, D. G. Gueurts, A. M. A. Pistorius, M. C. Feiters, R. J. M. Nolte and B. Zwanenburg, Chem.-Eur. J., 1998, 4, 127.

19 E. Beltrán, E. Cavero, J. Barbera, J. L. Serrano, A. Elduque and R. Gimenez, Chem.-Eur. J., 2009, 15, 9017.

20 S. J. Georges, Z. Tomovic, M. M. J. Smulders, T. F A. de Greef, P. E. L. G. Leclère, E. W. Meijer and A. P. H. J. Schenning, Angew. Chem., Int. Ed., 2007, 46, 8206.

21 J. Seo, J. W. Chung, E.-H. Jo and S. Y. Park, Chem. Commun., 2008, 2794.

22 L. J. Prins, J. Huskens, F. De Jong, P. Timmerman and D. N. Reinhoudt, Nature, 1999, 398, 498.

23 For a review, see: M. Fourmigué and P. Batail, Chem. Rev., 2004, 104, 5379.

24 (a) K. Heuzé, M. Fourmigué and P. Batail, J. Mater. Chem., 1999, 9, 2373; (b) S. A. Baudron, N. Avarvari, E. Canadell, P. Auban-Senzier and P. Patrick, Chem.-Eur. J., 2004, 10, 4498.

25 (a) K. Heuzé, M. Fourmigué, P. Batail, E. Canadell and P. AubanSenzier, Chem.-Eur. J., 1999, 5, 2971; (b) K. Heuzé, C. Mézière, M. Fourmigué, P. Batail, C. Coulon, E. Canadell, P. Auban-Senzier and D. Jérome, Chem. Mater., 2000, 12, 1898; (c) S. A. Baudron, C. Méziere, K. Heuzé, M. Fourmigué, P. Batail, P. Molinié and P. Auban-Senzier, J. Solid State Chem., 2002, 168, 668; (d) S. A. Baudron, P. Batail, C. Rovira, E. Canadell and R. Clérac, Chem. Commun., 2003, 1820; (e) S. A. Baudron, P. Batail, C. Coulon, R. Clérac, E. Canadell, V. Laukhin, R. Melzi, P. Wzietek, D. Jérome, P. Auban-Senzier and S. Ravy, J. Am. Chem. Soc., 2005, 127, 11785.

26 (a) S. A. Baudron, N. Avarvari, P. Batail, C. Coulon, R. Clérac, E. Canadell and P. Auban-Senzier, J. Am. Chem. Soc., 2003, 125, 11583; $(b)$ L. V. Zorina, S. S. Khasanov, S. V. Simonov, R. P. Shibaeva, L. A. Kushch, L. I. Buravov, E. B. Yagubskii, S. Baudron, C. Mézière, P. Batail, E. Canadell and P. AubanSenzier, Synth. Met., 2005, 155, 527.

27 A. S. Batsanov, M. R. Bryce, J. N. Heaton, A. J. Moore, P. J. Skabara, J. A. K. Howard, E. Orti, P. M. Viruela and R. Viruela, J. Mater. Chem., 1995, 5, 1689.

28 J. Garín, J. Orduna, M. Saviron, M. R. Bryce, A. J. Moore and V. Morisson, Tetrahedron, 1996, 52, 11063.

29 K. Bender, I. Hennig, D. Schweitzer, K. Dietz, H. Endres and H. J. Keller, Mol. Cryst. Liq. Cryst., 1984, 108, 359.

30 (a) R. Kuroda and S. F. Mason, J. Chem. Soc., Perkin Trans. 2, 1981, 167; (b) R. B. Kress, E. N. Duesler, M. C. Etter, I. C. Paul and D. Y. Curtin, J. Am. Chem. Soc., 1980, 102, 7709.

31 B. Suchod, A. Renault, J. Lajzerowicz and G. P. Spada, J. Chem. Soc., Perkin Trans. 2, 1992, 1839.

32 M. C. Etter, Acc. Chem. Res., 1990, 23, 120.

33 (a) R. Beerli and J. Rebeck Jr., Tetrahedron Lett., 1995, 36, 1813; (b) P. W. Baures, J. R. Rush, A. V. Wiznycia, J. Desper, B. A. Helfrish and A. M. Beatty, Cryst. Growth Des., 2002, 2, 653.

34 C. Rovira and J. J. Novoa, Chem.-Eur. J., 1999, 5, 3689.

35 P. Hudhomme, S. Le Moustarder, C. Durand, N. Gallego-Planas, N. Mercier, P. Blanchard, E. Levillain, M. Allain, A. Gorgues and A. Riou, Chem.-Eur. J., 2001, 7, 5070.

36 G. M. Sheldrick, SHELX97: Programs for Crystal Structure Analysis (Release 97-2), 1998.

37 A. Altomare, M. C. Burla, M. Camalli, G. L. Cascarano, C. Giacovazzo, A. Guagliardi, A. G. G. Moliterni, G. Polidori and R. Spagna, J. Appl. Crystallogr., 1999, 32, 115-119.

38 L. J. Farrugia, J. Appl. Crystallogr., 1999, 32, 837-838. 